\title{
Profitabilitas Sebagai Mediasi Pertumbuhan Penjualan dan Struktur Modal terhadap Nilai Perusahaan
}

\section{Bayu Ajie Santoso}

Sekolah Tinggi Ilmu Ekonomi Indonesia (STIESIA) Surabaya

bayuajiesantoso630@gmail.com

\section{Anindhyta Budiarti}

Sekolah Tinggi Ilmu Ekonomi Indonesia (STIESIA) Surabaya anindhytabudiarti@stiesia.ac.id
Abstrak
Penelitian ini bertujuan untuk menganalisis dan mengetahui pengaruh pertumbuhan penjualan dan struktur modal terhadap nilai perusahaan dengan profitabilitas sebagai variabel pemediasi. Sampel pada penelitian ini yaitu sebanyak 11 perusahaan properti dan real estate yang terdaftar di Bursa Efek Indonesia selama periode 2014-2018. Metode analisis yang digunakan adalah analisis jalur dengan menggunakan program SmartPLS versi 3.0. Hasil penelitian menunjukkan bahwa Sales Growth (SG) dan Debt to Equity Ratio (DER) berpengaruh positif dan signifikan terhadap Return on Equity (ROE). Sales Growth (SG) dan Return on Equity (ROE) berpengaruh negatif dan tidak signifikan serta Debt to Equity Ratio (DER) berpengaruh negatif dan signifikan terhadap Price to Book Value (PBV). Return on Equity (ROE) tidak memediasi pengaruh Sales Growth (SG) dan Debt to Equity Ratio (DER) terhadap Price to Book Value (PBV).

\section{Kata Kunci Pertumbuhan Penjualan, Struktur Modal (DER), Profitabilitas (ROE),} Nilai Perusahaan (PBV)
Abstract This research aimed to analyze and find out the effect of sales growth and capital structure on the firm value, with profitability as moderating variable. In line with, there were 11 Property and Real estate companies which were listed on Indonesia Stock Exchange 2014-2018 as samples. In addition, the data analysis technique used path analysis with Smart PLS 3.0. The research result concluded Sales Growth (SG) and Debt to Equity Ratio (DER) had positive and significant effect on Return On Equity (ROE). Meanwhile, Sales Growth (SG) and Return On Equity (ROE) had negaitve and insignificant effect as well as Debt to Equity Ratio (DER) had negaitve and significant effect on the Price to Book Value $(P B V)$. In short, profitability did not mediate the effect of Sales Growth (SG) and Debt to Equity Ratio (DER) on Price to Book Value $(P B V)$.

Keywords Sales Growth (SG), Capital Structure (DER), Profitability (ROE), Firm Value $(P B V)$ 


\section{PENDAHULUAN}

Perkembangan teknologi dan globalisasi mempengaruhi pertumbuhan perekonomian masyarakat saat ini, tak terkecuali pada perdagangan global sehingga menciptakan iklim bisnis yang lebih kompetitif. Seiring dengan meningkatnya perekonomian, pertumbuhan pada sektor bisnis industri properti dan real estate juga terus berkembang. Sektor bisnis indsutri ini merupakan salah satu sumber penerimaan yang berpotensi besar dalam peningkatan pertumbuhan ekonomi suatu negara. Adapun tujuan perusahaan dalam melakukan kegiatan bisnis yaitu untuk mencapai keuntungan maksimal dengan laba yang sebesar-besarnya. Sedangkan tujuan utama perusahaan adalah dapat memakmurkan para pemilik perusahaan maupun pemegang saham, serta memaksimalkan nilai perusahaan (Harjito dan Martono, 2012:2). Kemampuan perusahaan dalam menghasilkan profit sangat mempengaruhi nilai perusahaan yang ditunjukkan pada laporan keuangan. Hal ini diharapkan perusahaan dapat memakmurkan para pemilik saham dengan membagikan dividen yang besar.

Harga pasar saham yang diperdagangkan merefleksikan nilai perusahaan itu sendiri yang dapat diketahui dari kemampuan perusahaan dalam membagikan dividen. Semakin tinggi harga saham dan dividen yang dibagikan, maka semakin tinggi tingkat kemakmuran pemegang saham. Namun dalam perkembangannya, pertumbuhan pada sub sektor bisnis industri properti dan real estate saat ini tidak sesuai dengan peningkatan yang diharapkan oleh perusahaan. Perusahaan dihadapkan pada situasi dimana rata-rata nilai perusahaan mengalami fluktuasi yang cenderung rendah selama tahun 2014 hingga 2018.

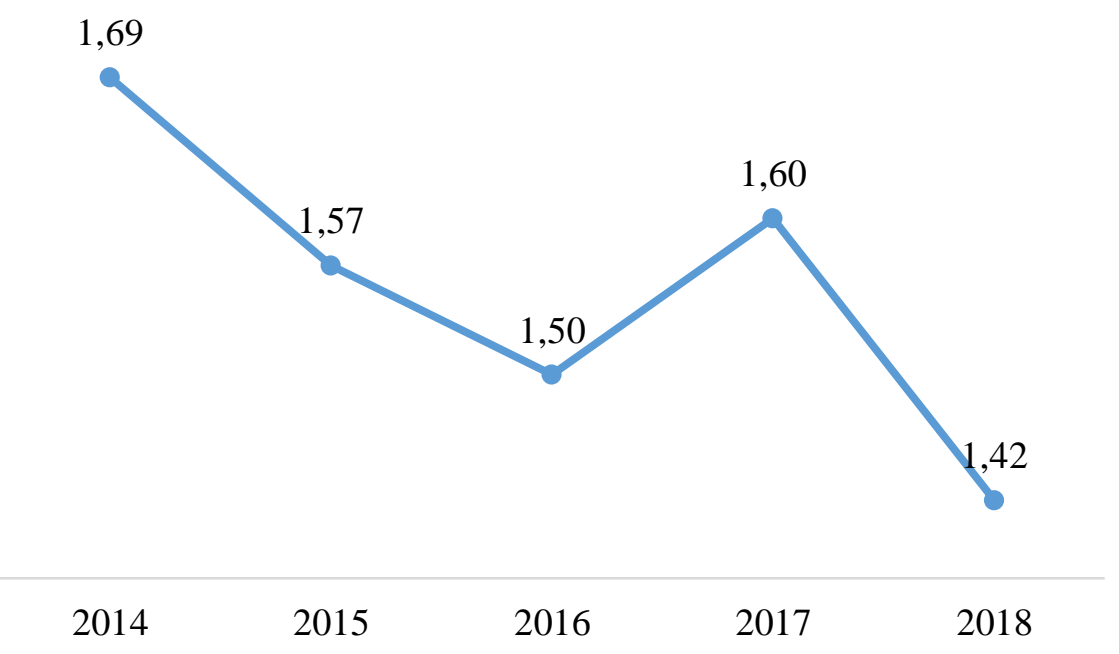

Gambar 1.1. Rata-rata PBV subsektor properti dan real estate 2014-2018 Sumber: Laporan keuangan, diolah

Berdasarkan grafik diatas, pada tahun 2014 menunjukkan rata-rata PBV tertinggi sebesar 1,69 kemudian terus menurun hingga 2016 pada rata-rata sebesar 1,50. Terjadi peningkatan sebesar 0,10 di tahun 2017, namun kemudian kembali turun pada 2018 yang menunjukkan rata-rata PBV terendah sebesar 1,42. Hal ini menunjukkan bahwa 
penurunan pada nilai perusahaan disebabkan oleh menurunnya harga saham properti dan real estate.

Adapun beberapa penyebab penurunan nilai perusahaan menurut Caesario (2018) yaitu, terbatasnya peningkatan harga properti, tingkat imbal hasil sewa yang relatif rendah, terdapat selisih yang cukup besar antara pasar properti primer dan sekunder, dan ketidakpastian mengenai pemilu presiden 2019. Hal ini menyebabkan investor untuk menahan tindakannya yang berdampak pada potensi depresiasi lanjutan pada harga saham properti dan real estate. Caesario (2018) juga menyatakan bahwa kenaikan inflasi dan suku bunga The Fed mengakibatkan kenaikan pula pada suku bunga Bank Indonesia yang mempengaruhi kenaikan suku bunga KPR sehingga terjadi penurunan permintaan properti. Kemudian adanya pasokan baru yang melebihi kebutuhan pasar, serta daya beli masyarakat yang mengalami penurunan dimana akibat ketatnya kebijakan dari otoritas pajak.

Badan Kebijakan Fiskal (2019) menyatakan bahwa indeks sektor konstruksi dan properti mencatatkan kinerja negatif sepanjang tahun 2018 yaitu sebesar 9,64\% year on year (yoy). Penurunan tersebut tercermin pada empat emiten yaitu PT Ciputra Development Tbk (CTRA), PT Bumi Serpong Damai Tbk (DSBE), PT Alam Sutera Realty Tbk (ASRI) dan PT Summarecon Agung Tbk (SMRA) yang mencatatkan penurunan pre-sales sebesar 1,8\% (yoy) yaitu Rp 20,3 triliun dari pre-sales tahun sebelumnya sebesar Rp 20,7 triliun. Nilai perusahaan menggambarkan kinerja suatu perusahaan yang menunjukkan prospek masa depan sebagai indikator penilaian pasar terhadap nilai perusahaan secara menyeluruh. Adapun pertumbuhan penjualan dan struktur modal dapat mempengaruhi nilai perusahaan. Pertumbuhan penjualan merupakan indikator terjadinya pertumbuhan perusahaan yang menjadi tolak ukur keberhasilan perusahaan (Hidayat, 2018:93). Penelitian Ugbor et al. (2018) menyatakan pengaruh positif signifikan pertumbuhan penjualan terhadap nilai perusahaan, namun hasil penelitian Asmawi (2018), Hidayat (2018) dan Rahman (2018) menyatakan pengaruh positif tidak signifikan. Berbeda dengan hasil penelitian Dang et al. (2019) menyatakan pertumbuhan penjualan berpengaruh negatif signifikan terhadap nilai perusahaan.

Nilai perusahaan juga dipengaruhi oleh struktur modal, dimana ketika perusahaan dapat menghasilkan laba yang tinggi sehingga memiliki jumlah laba ditahan yang besar dibandingkan dengan tingkat hutang yang dimiliki, maka perusahaan dapat memaksimalkan nilai perusahaan serta memakmurkan pemegang saham dengan mengeluarkan dividen yang besar. Penelitian Rahman (2018) dan Wulandari (2018) menyatakan struktur modal berpengaruh positif signifikan terhadap nilai perusahaan, sedangkan Dang et al. (2019), Asmawi (2018), serta Ramadhani dan Maryam (2018) menunjukkan pengaruh negatif signifikan terhadap nilai perusahaan. Makkulau et al. (2018) menyatakan pengaruh negatif tidak signifikan terhadap nilai perusahaan.

Penelitian ini menggunakan profitabilitas sebagai pemediasi pengaruh pertumbuhan penjualan dan struktur modal terhadap nilai perusahaan. Penelitian ini bermaksud untuk mengembangkan penelitian sebelumnya, dimana profitabilitas juga digunakan sebagai variabel pemediasi pengaruh pertumbuhan penjualan dan struktur modal terhadap nilai perusahaan yang dilakukan oleh Asmawi (2018), Makkulau et al. (2018) dan Rahman (2018).

Profitabilitas merupakan prospek bisnis saat ini yang berkaitan dengan kemampuan perusahaan dalam memperoleh keuntungan yang berhubungan dengan penjualan, total 
aktiva maupun modal sendiri. Penelitian Dang et al. (2019), Asmawi (2018), Makkulau et al. (2018), Ramadhani dan Maryam (2018), serta Wulandari (2018) menyatakan pengaruh positif signifikan profitabilitas terhadap nilai perusahaan, sedangkan Rahman (2018) menunjukkan pengaruh negatif signifikan terhadap nilai perusahaan.

Salah satu faktor yang mempengaruhi profitabilitas yaitu pertumbuhan penjualan. Pertumbuhan penjualan menggambarkan pencapaian perusahaan dimana semakin tinggi perutumbuhan penjualan maka akan meningkatan profitabilitas perusahaan. Penelitian Apriati et al. (2018), Asmawi (2018) dan Rahman (2018) menyatakan pengaruh positif signifikan pertumbuhan penjualan terhadap profitiabilitas, sedangkan Dang et al. (2019) dan Rahmawati et al. (2018) menunjukkan pengaruh negatif tidak signifikan terhadap profitabilitas.

Adapun struktur modal yang mempengaruhi profitabilitas. Struktur modal perusahaan yang lebih di dominasi oleh hutang dapat meminimalkan beban pajak, namun akan terjadi peningkatan pada beban bunga yang berakibat pada penurunan keuntungan perusahaan (Asmawi, 2018:84). Penelitian Rahman (2018) menyatakan struktur modal berpengaruh positif signifikan terhadap profitabilitas. Berbeda dengan hasil penelitian Dang et al. (2019), Nguyen et al. (2019), Rehan et al. (2018), Asmawi (2018), serta Das dan Swain (2018) yang menyatakan bahwa struktur modal berpengaruh negatif signifikan. Makkulau et al. (2018) menujukkan pengaruh negatif tidak signifikan terhadap profitabilitas.

Berdasarkan uraian diatas, maka dapat dirumuskan permasalahan penelitian yaitu: 1) Apakah pertumbuhan penjualan berpengaruh terhadap profitabilitas?, 2) Apakah struktur modal berpengaruh terhadap profitabilitas?, 3) Apakah pertumbuhan penjualan berpengaruh terhadap nilai perusahaan?, 4) Apakah struktur modal berpengaruh terhadap nilai perusahaan?, 5) Apakah profitabilitas berpengaruh terhadap nilai perusahaan?, 6) Apakah profitabilitas mampu memediasi pertumbuhan penjualan terhadap nilai perusahaan?, 7) Apakah profitabilitas mampu memediasi struktur modal terhadap nilai perusahaan?

\section{LANDASAN TEORI}

\subsection{Nilai Perusahaan}

Nilai perusahaan sebagai representasi dari kepercayaan masyarakat terhadap pencapaian perusahaan sejak didirikannya hingga saat ini. Peningkatan pada nilai perusahaan selaras dengan harapan pemilik, karena dengan meningkatnya nilai perusahaan, maka kesejahteraan pemilik dan para pemegang saham juga akan meningkat. Brigham dan Daves (dalam Makkulau et al., 2018:69) Nilai perusahaan akan berpengaruh terhadap kemakmuran para pemegang saham secara maksimum jika terjadi peningkatan pada harga saham perusahaan. Semakin tinggi harga saham maka semakin tinggi juga nilai perusahaan, sehingga perusahaan dapat membagikan dividen yang besar kepada investor sebagai bentuk memaksimalkan kemakmuran pemegang saham. Nilai perusahaan menunjukkan presepsi masyarakat atas keberhasilan perusahaan dalam menghasilkan keuntungan. Harga saham yang tinggi berakibat pada peningkatan nilai perusahaan, sehingga mampu menciptakan kepercayaan pasar terhadap kinerja perusahaan saat ini serta pada prospek perusahaan di masa depan, sehingga perusahaan dapat menjaga eksistensinya dalam jangka panjang. Nilai perusahaan diukur dengan rasio Price to Book Value (PBV) merupakan rasio yang menunjukkan seberapa besar pasar mengapresiasi nilai buku saham suatu perusahaan. Nilai buku per lembar saham dihitung berdasarkan 
perbandingan antara total ekuitas dengan jumlah lembar saham yang beredar. Semakin tinggi rasio yang diperoleh, maka semakin tinggi kepercayaan pasar terhadap prospek perusahaan.

\subsection{Pertumbuhan Penjualan}

$$
P B V=\frac{\text { Harga pasar per lembar saham }}{\text { Nilai buku per lembar saham }}
$$

Pertumbuhan penjualan mengambarkan aktualisasi keberhasilan investasi perusahaan pada periode sebelumnya yang dijadikan sebagai estimasi pertumbuhan di masa yang akan datang (Hidayat, 2018:93). Pertumbuhan penjualan juga digunakan menjadi indikator permintaan daya saing perusahaan. Pesatnya pertumbuhan suatu perusahaan akan mempengaruhi kapasitas dalam mempertahankan keuntungan serta berbagai kesempatan pada masa depan. Pertumbuhan penjualan merupakan salah satu kriteria penting dari penerimaan pasar suatu perusahaan, dimana penghasilan yang diperoleh atas penjualan barang atau jasa dalam periode tertentu, dapat digunakan untuk mengukur tingkat pertumbuhan penjualan. Pertumbuhan penjualan dihitung dengan rumus:

\subsection{Struktur Modal}

$$
\text { Sales Growth }=\frac{\text { Penjualan }_{t}-\text { Penjualan }_{(t-1)}}{\text { Penjualan }_{(t-1)}} \times 100 \%
$$

Weston dan Copeland (dalam Asmawi, 2018:19) menyatakan bahwa struktur modal merupakan susunan pendanaan jangka panjang perusahaan dengan hutang dan ekuitas. Struktur modal merefleksikan pendapatan jangka panjang perusahaan yang ditunjukkan oleh perbandingan hutang jangka panjang terhadap nilai sendiri. Perusahaan harus mencari alternatif pendanaan yang efisien, apabila perusahaan mempunyai struktur modal yang optimal. Struktur modal yang optimal merupakan struktur permodalan yang mampu meminimalkan biaya modal keseluruhan, sehingga dapat memaksimalkan nilai perusahaan (Harjito dan Martono, 2014:256).

Struktur modal adalah keserasian sistem permodalan antara hutang sebagai sumber dana eksternal dengan ekuitas sebagai sumber dana internal yang digunakan untuk melaksanakan aktivitas operasional jangka panjang perusahaan. Brigham dan Houston (dalam Wulandari, 2018:19) menyatakan bahwa implementasi struktur permodalan yang tepat, mampu meningkatkan kinerja perusahaan. Struktur modal yang optimal memiliki arti bahwa perusahaan menggunakan modal keseluruhan secara minimum untuk memaksimumkan nilai perusahaan. Maksimumnya nilai perusahaan merupakan tujuan manajemen untuk meningkatkan kemakmuran pemegang saham.

Struktur modal diukur dengan Debt to Equity Ratio (DER) merupakan rasio yang digunakan untuk mengukur kemampuan perusahaan dalam memenuhi kewajiban membayar hutang dengan modal sendiri.

\subsection{Teori Sinyal (Signaling Theory)}

$$
D E R=\frac{\text { Total liabilitas }}{\text { Total ekuitas }}
$$

Brigham dan Houston (dalam Wulandari, 2018:12) menyatakan bahwa teori sinyal merupakan suatu tindakan yang diambil oleh manajemen untuk menginformasikan bagaimana prospek perusahaan mendatang kepada investor. Teori sinyal dilakukan karena terjadi asimetri informasi antara perusahaan dengan pihak eksternal mengenai keadaan yang sebenarnya serta prospek masa depan perusahaan. Hutang sebagai sumber 
pendanaan memberikan sinyal positif dari investor yang tercermin melalui peningkatan pada harga saham. Sedangkan pendanaan melalui penerbitan saham memberikan presepsi negatif oleh investor yang dapat menurunkan nilai perusahaan. Hal ini menunjukkan bahwa perusahaan dengan sumber pendanaan hutang percaya pada kemampuannya dalam memperoleh laba unuk memenuhi kewajibannya, sebaliknya perusahaan dengan sumber pendanaan ekuitas mengindikasikan bahwa perusahaan tidak yakin pada kemampuannya dalam menghasilkan laba untuk memenuhi kewajibannya.

\subsection{Teori Keagenan (Agency theory)}

Teori keagenan merupakan sebuah gagasan mengenai pengendalian organisasi yang berlandaskan pada asumsi bahwa pemisahan kepemilikan dengan manajemen dapat menyebabkan potensi dimana kepentingan pemegang saham akan diabaikan. Hubungan keagenan merupakan hubungan pemegang saham dengan manajer. Hubungan ini akan efektif selagi dalam pengambilan keputusan investasi, manajer melaksanakannya secara konsisten searah dengan kepentingan pemegang saham. Namun ketika terjadi perbedaan antara kepentingan manajer dengan kepentingan pemegang saham, maka terdapat kemungkinan keputusan yang diambil oleh manajer merepresentasikan pilihannya dibandingkan dengan kepentingan pemegang saham. Hal ini akan mengakibatkan timbulnya masalah keagenan.

Masalah keagenan terjadi karena pemilik atau pemegang saham tidak memiliki akses terhadap aktivitas perusahaan sepenuhnya. Sering kali manajer bertindak berdasarkan kepentingan pribadi, sehingga kesejahteraan organisasi bukan menjadi prioritas utama. Jensen dan Meckling (dalam Asmawi, 2018:15) menyatakan adapun upaya yang dapat digunakan untuk mengurangi masalah keagenan, yaitu dengan investor melakukan pengawasan (monitoring) seperti pengawasan oleh dewan komisaris maupun dari instansi keuangan serta manajer sendiri melakukan pembatasan atas tindakannya (bonding). Dengan demikian, kepentingan pemilik atau pemegang saham diharapkan memperoleh preferensi yang seharusnya.

\subsection{Packing Order Theory}

Suatu perusahaan pasti akan terus berkembang dan membutuhkan modal yang besar untuk membiayai ekspansi usahanya, hal ini selaras dengan packing order theory. Namun sebaiknya perusahaan perlu melakukan analisis kebutuhan modal sebelum memutuskan memilih sumber pendanaan yang digunakan untuk mendanai kegiatan operasionalnya. Adapun sumber pendanaan yang dapat digunakan untuk memenuhi kebutuhan perusahaan yaitu sumber dana internal dan eksternal.

Perusahaan sebaiknya menggunakan sumber pendanaan berdasarkan urutan preferensi manajemen dan kontribusi masing-masing sumber pendanaan terhadap peningkatan nilai perusahaan yaitu sumber dana internal berupa laba ditahan kemudian sumber dana eksternal berupa hutang dan modal sendiri. Rehan et al. (2019:110) menyatakan perusahaan diharapkan menggunakan sumber pendanaan internal terlebih dahulu sebelum memilih hutang dan modal sendiri. Perusahaan yang membiayai kebutuhannya melalu pendanaan internal berarti laba ditahan yang dimiliki cukup besar. Perusahaan yang memilih hutang untuk mendanai kebutuhannya, menunjukkan di masa depan perusahaan harus memiliki posisi keuangan yang baik untuk melunasi kewajibannya. Perusahaan yang memutuskan untuk menerbitkan saham baru menunjukkan bahwa saham perusahaan dinilai terlalu tinggi. 
Myers (dalam Rahman, 2018:4) menyatakan bahwa perusahaan dengan tingkat profitabilitas yang tinggi menunjukkan tingkat hutang yang rendah, karena perusahaan dengan tingkat profitabilitas yang tinggi berarti memiliki sumber pendanaan internal yang baik. Packing order theory menyatakan bahwa perencanaan yang tepat sebagai keputusan pembiayaan melalui sumber dana internal, kemudian hutang dan apabila perusahaan belum mendapatkan dana yang cukup maka pembiayaan melalui ekuitas sebagai opsi terakhir yang tersedia sebagai opsi pendanaan eksternal (Rehan et al., 2019:110).

\subsection{Profitabilitas}

Profitabilitas merupakan tolak ukur kemampuan perusahaan dalam memperoleh keuntungan melalui aset keseluruhan perusahaan. Profitabilitas merupakan kemampuan perusahaan memperoleh keuntungan dalam hubungannya dengan penjualan, total aktiva maupun modal sendiri. Laba menjadi salah satu penilaian kinerja perusahaan, dimana semakin tinggi laba yang dihasilkan maka semakin tinggi pula keuntungan yang diperoleh investor serta kinerja perusahaan tersebut semakin baik.

Profitabilitas sebagai indikator dalam mengukur kinerja keuangan perusahaan. Suwardika dan Mustanda (dalam Wulandari, 2018:22) menyatakan profitabilitas berperan penting pada seluruh aspek bisnis suatu perusahaan karena dapat menunjukkan efisiensi serta keuntungan yang diperoleh investor. Profitabilitas menjadi salah satu pertimbangan bagi investor untuk berinvestasi, karena prospek perusahaan yang baik akan menunjukkan profitabilitas yang tinggi sehingga dapat menciptakan presepsi investor terhadap nilai perusahaan. Profitabilitas dapat diukur menggunakan rasio Retrun on Equity (ROE) merupakan rasio yang menunjukkan kemampuan perusahaan dalam menghasilkan laba bersih dari modal sendiri guna pengembalian ekuitas pemegang saham (Ramadhani dan Maryam, 2018:909). Semakin tinggi rasio yang dihasilkan, berarti bahwa perusahaan mampu menghasilkan laba lebih efektif dengan menggunakan modal sendiri.

$$
R O E=\frac{\text { Laba bersih }}{\text { Total ekuitas }} \times 100 \%
$$

\subsection{Rerangka Pemikiran}

Hubungan antara variabel penelitian dapat dinyatakan dalam rerangka pemikiran. Rerangka pemikiran dikembangkan untuk memudahkan pemahaman konsep yang digunakan sebagai berikut:

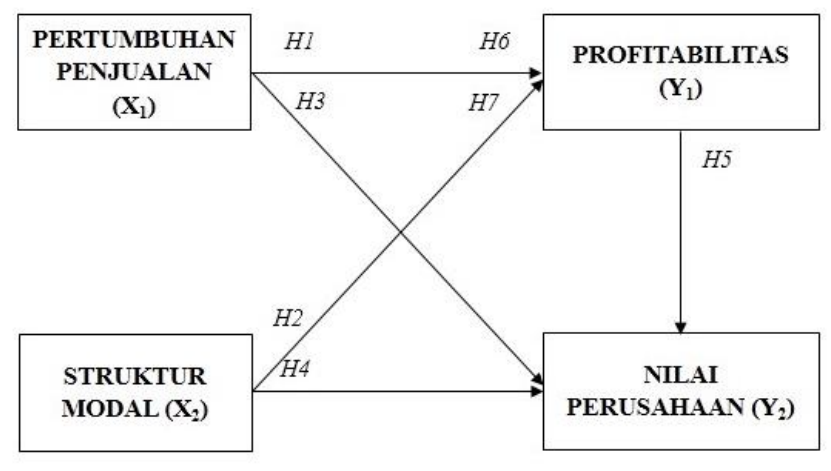

Gambar 2.1. Rerangka Pemikiran 


\subsection{Hipotesis Penelitian}

1. Pertumbuhan penjualan berpengaruh positif terhadap profitabilitas

2. Struktur modal berpengaruh positif terhadap profitabilitas

3. Pertumbuhan penjualan berpengaruh positif terhadap nilai perusahaan

4. Struktur modal berpengaruh positif terhadap nilai perusahaan

5. Profitabilitas berpengaruh positif terhadap nilai perusahaan

6. Profitabilitas memediasi pertumbuhan penjualan terhadap nilai perusahaan

7. Profitabilitas memediasi struktur modal terhadap nilai perusahaan

\section{METODOLOGI PENELITIAN}

Penelitian ini merupakan jenis penelitian kuantitatif dengan menggunakan jenis data sekunder yaitu data yang diperoleh secara tidak langsung melalui perantara. Sumber data diperoleh dari laporan tahunan serta laporan keuangan perusahaan.

Populasi dalam penelitian ini adalah 48 perusahaan properti dan real estate yang terdaftar di Bursa Efek Indonesia tahun 2014-2018. Sampel pada penelitian ini yaitu 11 perusahaan properti dan real estate yang terdaftar di Bursa Efek Indonesia selama periode 2014-2018 yang diperoleh dengan menggunakan metode pusposive sampling. Metode purposive sampling yaitu teknik pengambilan sampel dengan beberapa kriteria berdasarkan pertimbangan tertentu untuk memperoleh sampel yang substansial (Sugiyono, 2014:149). Pengumpulan data pada penelitian ini melalui dokumentasi beberapa sumber literatur seperti artikel, jurnal, buku, laporan tahunan serta laporan keuangan perusahaan yang dipublikasikan oleh Bursa Efek Indonesia melalui situs resminya yaitu www.idx.com. Metode analisis yang digunakan adalah analisis jalur dengan menggunakan model persamaan struktural (structural equation modeling, SEM) berbasis varian melalui program SmartPLS versi 3.0. Evaluasi model struktural dilakukan berdasarkan koefisien determinan dan pengujian signifikansi. Pengaruh tidak langsung dilakukan melalui pengujian efek mediasi berdasarkan prosedur Barron dan Kenny (1986).

\section{HASIL PENELITIAN}

Berdasarkan hasil analisis jalur, maka diperoleh hasil pengujian model struktural sebagai berikut:

Tabel 1. Hasil Uji Koefisien Determinan

\begin{tabular}{cc}
\hline Konstruk & Nilai R-Square \\
\hline ROE & 0,278 \\
PBV & 0,185 \\
\hline
\end{tabular}

Sumber: Data diolah

Uji Koefisien determinan digunakan untuk mengetahui besaran presentase varian yang dijelaskan berdasarkan nilai R-Square untuk setiap variabel laten endogen. Nilai RSquare variabel ROE sebesar $27,8 \%$ berarti model termasuk kategori moderat, sedangkan nilai R-Square variabel PBV sebesar $18,5 \%$ berarti model termasuk kategori lemah. Variabel ROE dapat dijelaskan oleh variabel SG dan DER sedangkan sisanya 72,2\% dijelaskan oleh variabel lain di luar model penelitian. Variabel PBV sebesar 18,5\% dapat 
dijelaskan oleh variabel SG, DER dan ROE sedangkan sisanya 81,5\% dijelaskan oleh variabel lain di luar model penelitian.

Tabel 2. Hasil Uji Signifikansi

\begin{tabular}{ccccc}
\hline Hipotesis & Path & $\begin{array}{c}\text { Original } \\
\text { Sample }\end{array}$ & T-Statistics & Keterangan \\
\hline H1 & SG $\rightarrow$ ROE & 0,395 & 3,049 & Signifikan \\
H2 & DER $\rightarrow$ ROE & 0,311 & 2,260 & Signifikan \\
H3 & SG $\rightarrow$ PBV & $-0,099$ & 0,425 & Tidak Signifikan \\
H4 & DER $\rightarrow$ PBV & $-0,448$ & 3,892 & Signifikan \\
H5 & ROE $\rightarrow$ PBV & 0,132 & 0,684 & Tidak Signifikan \\
\hline
\end{tabular}

Sumbe: Data diolah

Pengujian signifikansi digunakan untuk menguji hipotesis pengaruh hubungan antar variabel laten. Hasil analisis pengaruh SG terhadap ROE menunjukkan nilai original sample positif sebesar 0,395 dengan nilai T-Statistics sebesar 3,049 (T-Statistics $>t$ value 1,96). Hal ini berarti hubungan antar variabel adalah searah, maka dapat disimpulkan bahwa hipotesis 1 diterima dan memperoleh dukungan dengan pengaruh signifikan. Kemudian, pengaruh DER terhadap ROE menunjukkan nilai original sample positif sebesar 0,311 dengan nilai $T$-Statistics sebesar 2,260 ( $T$-Statistics $>t$ value 1,96). Hal ini berarti hubungan antar variabel adalah searah, maka dapat disimpulkan bahwa hipotesis 2 diterima dengan pengaruh signifikan.

Selanjutnya pengaruh SG terhadap PBV menunjukkan nilai original sample negatif sebesar -0,099 dengan nilai T-Statistics sebesar 0,425 (T-Statistics < t value 1,96). Hal ini berarti hubungan antar variabel adalah berlawanan, maka dapat disimpulkan bahwa hipotesis 3 ditolak dengan pengaruh tidak signifikan. Kemudian pengaruh DER terhadap PBV menunjukkan nilai original sample negatif sebesar -0,448 dengan nilai T-Statistics sebesar 3,892 (T-Statistics > t value 1,96). Hal ini berarti hubungan antar variabel adalah berlawanan, maka dapat disimpulkan bahwa hipotesis 4 ditolak dengan pengaruh signifikan. Sedangkan pengaruh ROE terhadap PBV menunjukkan nilai original sample positif sebesar 0,132 dengan nilai $T$-Statistics sebesar 0,684 (T-Statistics < $t$ value 1,96). Hal ini berarti hubungan antar variabel adalah searah, maka dapat disimpulkan bahwa hipotesis 5 diterima dengan pengaruh tidak signifikan.

Tabel 3. Hasil Pengujian Pengaruh Tidak Langsung

\begin{tabular}{ccccc}
\hline Hipotesis & Path & $\begin{array}{c}\text { Original } \\
\text { Sample }\end{array}$ & T-Statistics & Keterangan \\
\hline H6 & SG $\rightarrow$ ROE $\rightarrow$ PBV & 0,052 & 0,507 & Tidak Signifikan \\
H7 & DER $\rightarrow$ ROE $\rightarrow$ PBV & 0,041 & 0,626 & Tidak Signifikan \\
\hline
\end{tabular}

\section{Sumber: Data diolah}

Hasil pengujian pengaruh tidak langsung SG terhadap PBV melalui ROE menunjukkan nilai original sample positif sebesar 0,041. Nilai T-Statistics sebesar 0,626 (T-Statistics < $t$ value 1,96), hal ini berarti variabel profitabilitas bukan merupakan mediator dalam penelitian ini. Hasil pengujian mediasi ROE menunjukkan pengaruh SG terhadap ROE 
signifikan dengan T-Statistics sebesar 3,049 (T-Statistics $>t$ value 1,96) dan hubungan ROE dengan PBV tidak singnifikan pada T-Statistics sebesar 0,684 (T-Statistics $<t$ value 1,96). Sedangkan pengaruh SG terhadap PBV tidak signifikan dengan T-Statistics ebesar 0,425 (T-Statistics $<t$ value 1,96). Maka dapat disimpulkan bahwa ROE tidak memediasi hubungan SG terhadap PBV. Pengaruh ROE pada penelitian ini disebut sebagai partial mediation. Dengan demikian hipotesis 6 ditolak dengan pengaruh tidak signifikan.

Hasil pengujian pengaruh tidak langsung DER terhadap PBV melalui ROE menunjukkan nilai original sample positif sebesar 0,052. Nilai T-Statistics sebesar 0,507 ( $T$-Statistics $<$ $t$ value 1,96), hal ini berarti variabel profitabilitas bukan merupakan mediator dalam penelitian ini. Hasil pengujian mediasi ROE menunjukkan pengaruh DER terhadap ROE signifikan dengan $T$-Statistics sebesar 2,260 (T-Statistics $>t$ value 1,96) dan hubungan ROE dengan PBV tidak singnifikan pada T-Statistics sebesar 0,684 (T-Statistics $<t$ value 1,96). Sedangkan pengaruh DER terhadap PBV signifikan dengan T-Statistics sebesar 3,892 ( $T$-Statistics $>t$ value 1,96). Dengan demikian ROE tidak memediasi pengaruh DER terhadap PBV. Pengaruh ROE pada penelitian ini disebut sebagai partial mediation, maka dapat disimpulkan bahwa hipotesis 7 ditolak dengan pengaruh tidak signifikan.

\section{KESIMPULAN}

Berdasarkan hasil analisis data dan pembahasan yang telah dikemukakan, maka penelitian ini dapat disimpulkan sebagai berikut:

1. Hasil pengujian menunjukkan bahwa pertumbuhan penjualan berpengaruh positif signifikan terhadap profitabilitas yang diukur dengan variabel Return on Equity (ROE) pada perusahaan properti dan real estate yang terdaftar di Bursa Efek Indonesia. Hal ini berarti bahwa tingkat penjualan perusahaan mempengaruhi peningkatan profitabilitas. Selagi penambahan biaya operasional dan aktiva baru dapat meningkatkan penjualan perusahaan maka profitabilitas juga akan terus meningkat.

2. Hasil pengujian menunjukkan bahwa struktur modal yang diukur dengan variabel Debt to Equity Ratio (DER) berpengaruh positif signifikan terhadap profitabilitas yang diukur dengan variabel Return on Equity (ROE) pada perusahaan properti dan real estate yang terdaftar di Bursa Efek Indonesia. Hal ini berarti bahwa struktur modal yang memiliki komposisi hutang lebih besar daripada modal sendiri akan mengurangi beban pajak, karena terdapat bunga yang dapat digunakan untuk membayar pajak, sehingga mampu meningkatkan laba perusahaan dan peningkatan pada profitabilitas dapat dicapai.

3. Hasil pengujian menunjukkan bahwa pertumbuhan penjualan berpengaruh negatif tidak signifikan terhadap nilai perusahaan yang diukur dengan variabel Price to Book Value (PBV) pada perusahaan properti dan real estate yang terdaftar di Bursa Efek Indonesia. Hal ini berarti bahwa rendahnya tingkat penjualan tidak mempengaruhi peningkatan pada nilai perusahaan karena penjualan bukan merupakan jumlah pendapatan keseluruhan yang diterima perusahaan dan belum dikurangi dengan biaya lain-lain. Tingkat penjualan perusahaan tidak mempengaruhi investor dalam berinvestasi sehingga tidak mempengaruhi peningkatan maupun penurunan nilai perusahaan. 
4. Hasil pengujian menunjukkan bahwa struktur modal yang diukur dengan variabel Debt to Equity Ratio (DER) berpengaruh negatif signifikan terhadap nilai perusahaan yang diukur dengan variabel Price to Book Value (PBV) pada perusahaan properti dan real estate yang terdaftar di Bursa Efek Indonesia. Hal ini berarti bahwa semakin besar hutang akan memperbesar risiko yang ditanggung oleh para pemegang saham, sehingga dapat menurunkan nilai perusahaan.

5. Hasil pengujian menunjukkan bahwa profitabilitas yang diukur dengan variabel Return on Equity (ROE) berpengaruh positif tidak signifikan terhadap nilai perusahaan yang diukur dengan variabel Price to Book Value (PBV) pada perusahaan properti dan real estate yang terdaftar di Bursa Efek Indonesia. Hal ini berarti bahwa profitabilitas tidak mempengaruhi nilai perusahaan karena adanya pengaruh eksternal yang mempengaruhi pertimbangan calon investor dimana prospek perusahaan bukan menjadi penentu kenaikan harga saham.

6. Hasil pengujian menunjukkan bahwa pertumbuhan penjualan mempengaruhi nilai perusahaan properti dan real estate yang terdaftar di Bursa Efek Indonesia yang diukur dengan variabel Price to Book Value (PBV) tanpa melalui profitabilitas yang diukur dengan variabel Return on Equity (ROE). Profitabilitas tidak mampu memediasi pertumbuhan penjualan terhadap nilai perusahaan. Meskipun pertumbuhan penjualan dapat meningkatkan profitabilitas tetapi karena adanya pengaruh faktor eksternal menyebabkan profitabilitas tidak mampu mempengaruhi peningkatan nilai perusahaan.

7. Hasil pengujian menunjukkan bahwa struktur modal mempengaruhi nilai perusahaan properti dan real estate yang terdaftar di Bursa Efek Indonesia yang diukur dengan variabel Price to Book Value (PBV) tanpa melalui profitabilitas yang diukur dengan variabel Return on Equity (ROE). Profitabilitas tidak mampu memediasi struktur modal terhadap nilai perusahaan. Meskipun perusahaan menunjukkan prospek yang baik, namun manajemen tidak menggunakan hutang secara optimal sehingga memberikan sinyal negatif yang mengakibatkan investor tidak ingin berinvestasi yang berdampak pada penurunan nilai perusahaan.

\section{Saran}

Berdasarkan kesimpulan dari penelitian ini, maka penulis dapat memberikan saran sebagai berikut:

1. Bagi perusahaan, sebaiknya memperhatikan pertumbuhan penjualan karena semakin tinggi tingkat penjualan dapat menunjukkan prospek perusahaan yang baik sehingga mampu meningkatkan profitabilitas serta mengakibatkan peningkatan pada nilai perusahaan. Perusahaan juga diharapkan dapat menentukan proporsi hutang pada tingkat tertentu dengan manfaat yang diharapkan lebih besar daripada biaya yang harus ditanggung sebagai sumber pendanaannya yang diharapkan dapat meningkatkan profitabilitas sehingga nilai perusahaan juga meningkat.

2. Bagi investor, dalam memberikan suatu penilaian terhadap suatu perusahaan, sebaiknya mempertimbangkan faktor pertumbuhan penjualan, struktur modal, profitabilitas serta faktor-faktor lain yang mempengaruhi nilai perusahaan. Investor juga diharapkan memilih saham yang memiliki rasio profitabilitas baik dengan rasio pasar yang murah sehingga nilai perusahaan berpotensi dapat meningkat dan memberikan prospek baik pada masa mendatang dengan return yang inggi. 
3. Bagi peneliti berikutnya, sebaiknya dapat melakukan penelitian dengan memperluas sampel perusahaan dari jenis industri yang berbeda pada perusahaan yang terdaftar di Bursa Efek Indonesia. Peneliti juga disarankan dapat menambah atau menggunakan faktor-faktor lain yang mempengaruhi nilai perusahaan selain pertumbuhan penjualan, struktur modal dan profitabilitas sehingga dapat memberikan hasil penelitian terbaru pada masa mendatang serta menggunakan variabel lain selain profitabilitas sebagai variabel mediasi untuk mendapatkan pengaruh yang lebih besar antara variabel independen terhadap variabel dependen.

\section{DAFTAR PUSTAKA}

Apriati, T., M. A. Salim., dan A. A. Priyono. 2018. Pengaruh PertumbuhanPenjualan, Perputaran Modal Kerja dan Likuiditas Terhadap Profitabilitas (Studi Kasus Pada Perusahaan Aneka Industri yang Terdaftar di Bursa Efek Indonesia Periode 2013-2016). E-Jurnal Riset Manajemen 7(2): 46-58.

Asmawi, A. R. G. 2018. Pengaruh Struktur Modal, Ukuran Perusahaan, Pertumbuhan Penjualan, dan Good Corporate Governance Terhadap Nilai Perusahaan Dengan Profitiabilitas Sebagai Variabel Intervening (Studi Empiris Pada Perusahaan Manufaktur yang Terdaftar di Bursa Efek Indonesia (BEI) Tahun 2013-2016). Skripsi. Fakultas Ekonomi Universitas Islam Indonesia. Yogyakarta.

Badan Kebijakan Fiskal. 2019. Tinjauan Ekonomi, Keuangan, dan Fiskal. Edisi Satu. Maret. BKF Kementrian keuangan. Jakarta.

Brigham E.F., dan J.F. Houston. 2018. Dasar-Dasar Manajemen Keuangan. Edisi Keempat belas. Buku 1. Salemba Empat. Jakarta.

Caesario, E. B. 2018. 2018, Sektor Properti Diprediksi Masih Lesu. https://m.bisnis.com/amp/read/20180109/192/724951/2018-sektorproperti-diprediksi-masih-lesu. 18 Nopember 2019 (19:28).

Dang, H. N., V. T. T. Vu., X. T. Ngo., dan H. T. V. Hoang. 2019. Study the Impact of Growth, Firm Size, Capital Structure, and Profitability on Enterprise Value: Evidence of Enterprises in Vietnam. The Journal of Corporate Accounting \& Finance 30(10): 144-160.

Das, C. P., dan R. K. Swain. 2018. Influence of Capital Structure on Financial Performance. KIIT Journal of Management 14(1): 161-170.

Harjito, A., dan Martono. 2012. Manajemen Keuangan. Edisi Kedua. Ekonesia. Yogyakarta.

Hidayat, M. 2018. Pengaruh Manajemen Pajak, Pertumbuhan Penjualan dan Ukuran Perusahaan Terhadap Nilai Perusahaan Pada Perusahaan Manufaktur di BEI Periode 2014-2016. Measurement: Jurnal Akuntansi 12(2): 90-100.

Makkulau, A. R., F. Amin., dan A. Hakim. 2018. Pengaruh Struktur Modal Terhadap Nilai Perusahaan Dengan Profitabilitas Sebagai Variabel Intervening Pada 
Perusahaan Properti dan Real estate yang Terdaftar di Bursa Efek Indonesia. Sigma: Journal of Economic and Business 1(2): 67-74.

Nguyen, V. C., T. N. L. Nguyen, T. T. P. Tran, dan T. T. Nghiem. 2019. The Impact of Financial Leverage on the Pofitability of Real estate Companies: A Study from Vietman Stock Exchange. Management Science Letters 9: 2315-2326.

Palupi, R. S. dan S. Hendiarto. 2018. Kebijakan Hutang, Profitabilitas dan Kebijakan Dividen Pada Nilai Perusahaan Properti \& Real estate. Jurnal Ecodemica 2(2): 177-185.

Rahman, K. 2018. Pengaruh Struktur Modal dan Pertumbuhan Penjualan Terhadap Nilai Perusahaan Dengan Kinerja Keuangan Sebagai Variabel Mediating. Tesis. Universitas Muhammadiyah Surakarta. Surakarta.

Rahmawati, S., M. A. Salim., dan M. K. ABS. 2018. Pengaruh Likuiditas, Pertumbuhan Penjualan, Perputaran Modal Kerja, Ukuran Perusahaan dan Leverage Terhadap Profitabilitas Perusahaan (Studi Pada Perusahaan Manufaktur yang Terdaftar pada BEI Tahun 2014-2016). E-Jurnal Riset Manajemen 7(10): 93107.

Ramadhani, Y. C., dan D. Maryam. 2018. Pengaruh Struktur Modal, Profitabilitas dan Nilai Pasar Terhadap Nilai Perusahaan Dengan Dividend Sebagai Variabel Moderasi. Prosiding Seminar Nasional: Manajemen, Akuntansi dan Perbankan 1(1): 904-923.

Rehan, M., J. Alvi., dan S. Khatri. 2019. The Role of Capital Structure on Firm's Profitability of Listed Cement Sector in Pakistan Stock exchange. Saudi Journal of Economics and Finance 3(3): 107-116.

Ugbor, R. O., U. L., Onyekwelu., dan G. Eneh. 2018. Effect of Firm's Variables on Corporate Valuation of Manufacturing Sector in Nigeria. European Journal of Business and Management 10(6): 48-57.

Sugiyono. 2014. Metode Penelitian Manajemen. Cetakan Kedua. Alfabeta. Bandung.

Wulandari, D. 2018. Pengaruh Growth Opportunity, Struktur Modal, Profitabilitas dan Tax Avoidance Terhadap Nilai Perusahaan Pada Perusahaan Properti dan Real estate yang Terdaftar di BEI Periode 2012-2016. Skripsi. Fakultas Ekonomi dan Bisnis Islam Institut Agama Islam Negeri Surakarta. Surakarta. 